\title{
An Overview of Environmental Education for Millennial Visitors in Indonesian Botanic Gardens
}

\author{
Rosniati A Risna ${ }^{1 *}$, Anggun R Gumilang ${ }^{2}$ \\ ${ }^{1}$ Research Center for Plant Conservation and Botanic Gardens, Indonesian Institute of Sciences, Bogor, West Java 16122, Indonesia \\ ${ }^{2}$ Cibodas Botanic Gardens, Indonesian Institute of Sciences, Cianjur, West Java 43253, Indonesia
}

\begin{abstract}
In an attempt to meet the information and education needs of millennial visitors - the new tourism frontiers - in industrial revolution 4.0 era, environmental education program in Indonesian Botanic Gardens (IBGs) has applied a new paradigm. As the world become more digital, the IBGs has also developed more digital programs in terms of environment, biology and conservation education. There are mobile apps for self-guided tours, digital class for various topics related with horticulture practices, virtual adventurous games, online reservation, are to name some. Annual numbers of IBGs visitors showed increasing trends in period of study, which was probably caused by increasing quality of information, education program, digital facilities, and displays, including photo spots. This paper will describe how IBGs play important role in supporting the Sustainable Development Goals (SDGs) in quality education, as well as Target 14 of Global Strategy for Plant Conservation (GSPC) by making more engagement with millennial visitors.
\end{abstract}

Keywords: Indonesian Botanic Gardens, education, industrial revolution 4.0, SDGs, GSPC

Received: 01 May 2019 Revised: 10 June 2019 Accepted: 17 June 2019

\section{Introduction}

Environmental education began to grow in the last century in the form of study of nature, conservation and outdoor education. Early in this century, UNESCO declared "Decade of Education for Sustainable Development (DESD)". The launch of the UN DESD (2005-2014) triggered a global movement to reorient education to address the challenges of sustainable development. Furthermore, UNESCO is entrusted to lead and coordinate the Education 2030 Agenda, which is part of a global movement through 17 Sustainable Development Goals (SDGs) by 2030 (Leicht et al., 2018).

Notwithstanding the conventional wisdom, however, many children as millennial generation today spend very little time outdoors. Respecting our history, and knowing the benefits of outdoor experiences, educators may wish to provide young generation both richer environments and extended time in them. Young generation should be provided by play spaces as their "habitats" --places where children can live (Rivkin, 2000).

Providing such places where children can live-play and learn, botanic gardens have an obvious and vital role in conserving biodiversity, especially plants. Increasing knowledge concerning biodiversity conservation is a frequently stated aim of environmental education (Williams et al, 2015). With over 2500 botanic gardens around the world receiving more than 300 million visitors annually

* Corresponding Author:

Rosniati A Risna

Research Center for Plant Conservation and Botanic Gardens, Indonesian Institute of Sciences, Bogor, West Java 16122, Indonesia

Phone: +622518322187 Fax: +622518322187

e-mail: rosniati.apriani.risna@lipi.go.id altogether (Botanic Gardens Conservation International, 2012), botanic gardens are uniquely placed to teach people about the importance of plants in our lives and in the global ecosystem. It makes botanic gardens are important centres for education (Willison, 1994; Botanic Gardens Conservation International, 1994). Apart from conservation and research, monitoring and information management, education and public awareness are main elements of botanic garden's global mission in conservation (Wyse-Jackson \& Sutherland, 2000) and Target 14 of the Global Strategy for Plant Conservation (Sharrock, 2011; Convention on Biological Diversity, 2012).

Since engagement and education is the means through which plant conservation targets can be achieved to raise public awareness of the importance of plant diversity (Wyse-Jackson \& Sutherland, 2000; Cerati et al., 2018), botanic gardens is necessarily to improve their education program. The developing roles of botanic gardens in biodiversity conservation, environmental education and sustainable development provide great opportunities and responsibilities for institutions throughout the world (Wyse-Jackson \& Sutherland, 2000).

Botanic Gardens under the Indonesian Institute of Sciences (LIPI) comprises Bogor Botanic Gardens (KRB) and Cibodas Botanic Gardens (KRC) in West Java, Purwodadi Botanic Gardens (KRP) in East Java, and Eka Karya Bali Botanic Gardens (KREK) in Bali. These four Gardens are located in different province and ecoregion (Purnomo et al., 2015), all have functions for plant conservation, research, education, tourism, and ecosystem services that are mandated in Presidential Decree No. 93/2011 (Pemerintah Republik Indonesia, 2011). With totally more than 2.3 million visitors a year, these four Gardens play vital role in outdoor education in terms of environmental education to raise people awareness towards nature and environment. Thus, LIPI Botanic Gar- 
dens or Indonesian Botanic Gardens are highly potential to significantly contribute in achievement of SDG Target 4 (quality education), and GSPC Target 14 (education for plant conservation) at national level, as well as embracing young people to care about their surrounding environment. As living laboratories, botanic gardens are not substitutes for study in natural areas but should be viewed as complementary, and they offer several advantages to the latter (Bennett, 2014).

Most school visits to LIPI Botanic Gardens are usually one-day trips or last just a few hours because of this limited period of time. The challenge is how such a short experience can have an impact on youth's learning or

\section{Methods}

\section{Research Site}

In order to determine how LIPI Botanic Gardens contribute to achieve SDGs and GSPC Target 14 by making engagement with millennial visitors, this study does a diagnosis of educational tools and activities in botanic gardens (BG) under Indonesian Institute of Sciences (LI$\mathrm{PI})$. The following $4 \mathrm{BGs}$ were selected as the research sites: Bogor BG (KRB), Cibodas BG (KRC), Purwodadi BG (KRP), and Eka Karya Bali BG (KREK), all are registered in Botanic Gardens Conservation International (BGCI).

\section{Results}

Four LIPI Botanic Gardens constituted in this study located in different provinces in Indonesia, with different focus on living plant collections according to their ecoregion representative. These four gardens are diverse, and their activities vary depending on funding sources, capacity, location, size, and governance (Tab. 1). They are well-visited sites of school field trips, family outings, and community events, with totally estimating 2.3 million visits per year. All Gardens have their own websites with information on educational activities, research and conservation. Ten activity grouping to meet GSPC Target 14 and SDG 4 were identified (Tab. 2). We observed that visits are directed to various groups, but educational visits are especially to schools. KRB even applies $50 \%$ special discount of fee entrance for school groups to promote educational visits. millennial visitors, both cognitively and affectively. Related to industrial revolution 4.0 where people are encouraged to use more digital and broadband in terms of their need in information and education, LIPI Botanic Gardens are facing new challenge to provide both more interactive and digital information to educate people especially millennial generation. Despite their historical heritage status, does each Garden more 'people-oriented' in terms of education? This study then was conducted to explore their strategy and program or activities to respond these challenges.

\section{Research Materials}

An exploratory study was carried out on their institutional websites, social media, and annual reports in period of 2014-2018. Educational activities available to the public and reported at the website and annual reports were identified. These activities were classified according to the aims of GSPC Target 14 underlining education and Target 15 for capacity building (Cerati, 2018). Then all activities were classified into manual and digital version. Availability of visitor education center facility is also observed.

Facilities and program for environmental education in Indonesian Botanic Gardens studied covering the presence of visitor education center, modules or worksheets, interactive media, as well as in-house and outreach education programs development (Tab. 3). Amongst the four Gardens, only KRC has developed web-based courses using social learning network (SLN) in Edmodo website, in 2016-2018. It underlined 12 subjects, equipped with video and e-book talking about main things related to the botanic gardens core competence (Tab. 4).

How Environmental Education in LIPI Botanic Gardens related to Sustainable Development Goals are presented in Table 5. Six Goals of SDGs were addressed in LIPI's botanic gardens environmental education programs.

Table 1. Basic information of LIPI Botanic Gardens in this study

\begin{tabular}{|c|c|c|c|c|c|c|c|c|}
\hline \multirow{2}{*}{$\begin{array}{l}\text { Botanic } \\
\text { Gardens }\end{array}$} & \multirow{2}{*}{$\begin{array}{c}\text { Year } \\
\text { established }\end{array}$} & \multirow{2}{*}{$\begin{array}{l}\text { Area } \\
\text { (ha) }\end{array}$} & \multirow{2}{*}{ Ecoregion } & \multirow{2}{*}{$\begin{array}{c}\text { Annual } \\
\text { Visitors* }\end{array}$} & \multirow{2}{*}{$\begin{array}{c}\text { Species } \\
\text { collected }^{* *}\end{array}$} & \multirow{2}{*}{ Accessibility } & \multicolumn{2}{|c|}{ Entrance fee (Rp) } \\
\hline & & & & & & & domestic & foreigners \\
\hline KRB & 1817 & 87 & $\begin{array}{l}\text { Western Java } \\
\text { rainforest }\end{array}$ & $1,102,678$ & 3,930 & $\begin{array}{l}\text { Within city; } 56 \mathrm{~km} \\
\text { from Jakarta }\end{array}$ & 14,000 & 25,000 \\
\hline $\mathrm{KRC}$ & 1852 & 85 & $\begin{array}{l}\text { Western Java } \\
\text { mountain forest }\end{array}$ & 560,344 & 1,586 & $\begin{array}{c}80 \mathrm{~km} \text { from } \\
\text { Bandung; } 100 \mathrm{~km} \\
\text { from Jakarta }\end{array}$ & 16,500 & 25,000 \\
\hline KRP & 1941 & 85 & $\begin{array}{l}\text { Eastern Java } \\
\text { rainforest }\end{array}$ & 192,015 & 2,027 & $\begin{array}{l}65 \mathrm{~km} \text { from } \\
\text { Malang City }\end{array}$ & 9,500 & 15,500 \\
\hline KREK & 1959 & 157.5 & $\begin{array}{l}\text { Java-Bali } \\
\text { mountain } \\
\text { rainforest }\end{array}$ & 492,205 & 1,510 & $\begin{array}{c}60 \mathrm{~km} \text { from } \\
\text { Denpasar City }\end{array}$ & 9,000 & 17,700 \\
\hline
\end{tabular}




\begin{tabular}{lcccc}
\hline Education Activities & KRB & KRC & KRP & KREK \\
\hline Educational visit & $\mathrm{V}$ & $\mathrm{V}$ & $\mathrm{V}$ & $\mathrm{V}$ \\
Educational materials & $\mathrm{V}$ & $\mathrm{V}$ & $\mathrm{V}$ & $\mathrm{V}$ \\
Biodiversity exhibitions & $\mathrm{V}$ & $\mathrm{V}$ & $\mathrm{V}$ & $\mathrm{V}$ \\
Library & $\mathrm{V}$ & $\mathrm{V}$ & $\mathrm{V}$ & $\mathrm{V}$ \\
Community events & $\mathrm{V}$ & - & $\mathrm{V}$ \\
Videos & $\mathrm{V}$ & $\mathrm{V}$ & $\mathrm{V}$ & $\mathrm{V}$ \\
Environmental interpretation & $\mathrm{V}$ & $\mathrm{V}$ & $\mathrm{V}$ \\
Interactive educational activities & $\mathrm{V}$ & $\mathrm{V}$ & $\mathrm{V}$ \\
Educational workshops/training & $\mathrm{V}$ & $\mathrm{V}$ & $\mathrm{V}$ \\
Applications (smartphone) & $\mathrm{V}$ & $\mathrm{V}$ & $\mathrm{V}$ & $\mathrm{V}$ \\
\hline
\end{tabular}

Table 2. Educational activities related to biodiversity and environment in each Botanic Gardens (Target 14 GSPC) and SDGs 4

Table 3. Facilities and program for environmental education in Indonesian Botanic Gardens

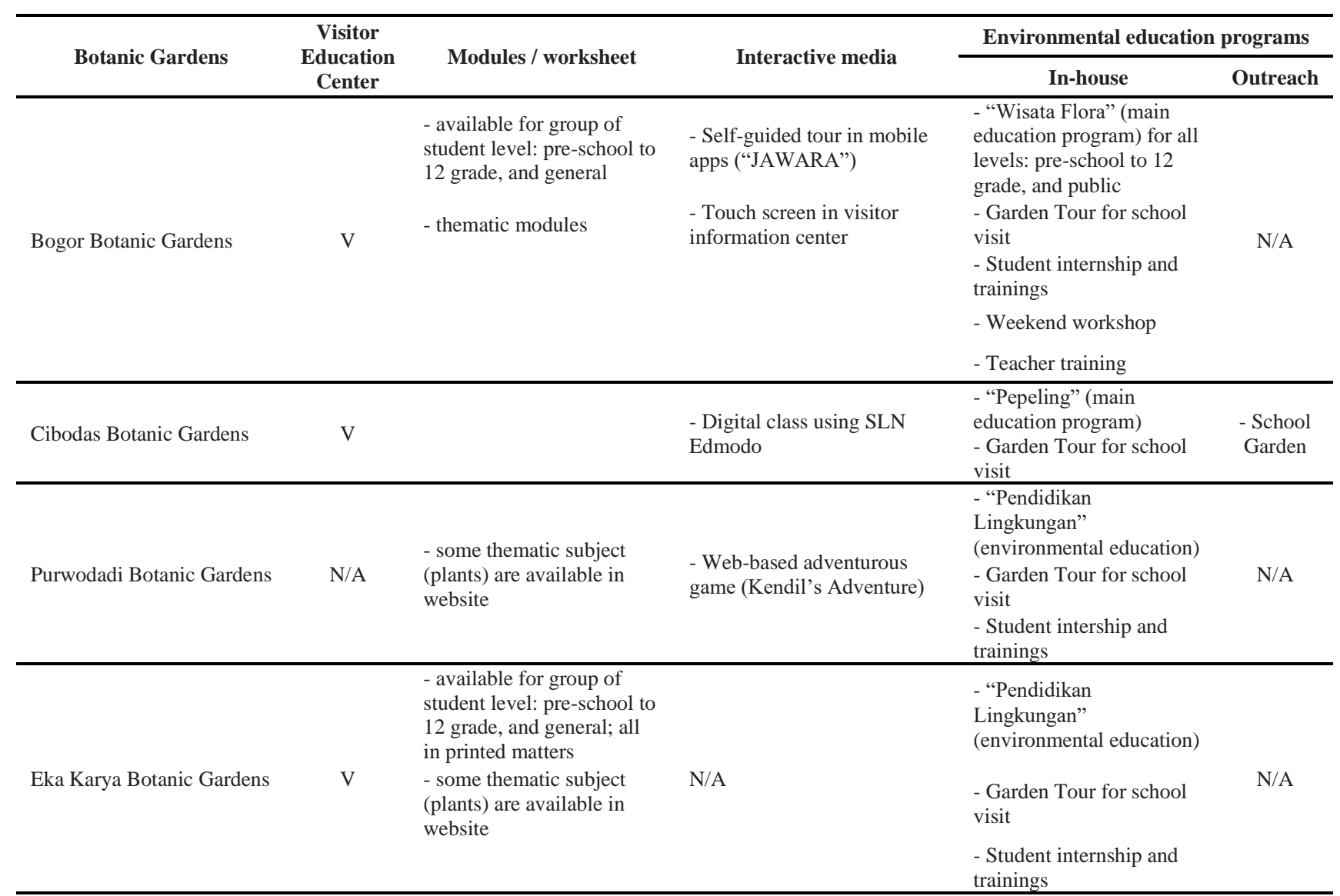


Table 4. Digital Class Developed by KRC Using SLN Edmodo

\begin{tabular}{lc}
\hline \multicolumn{1}{c}{$\begin{array}{c}\text { SLN topics } \\
\text { (all in Indonesian language) }\end{array}$} & $\begin{array}{c}\text { Duration } \\
\text { (hours : minutes) }\end{array}$ \\
\hline 1. Botanic Gardens & 01.30 \\
2. Cibodas Botanic Gardens & 01.20 \\
3. Plants Nomenclature & 01.30 \\
4. Plant Description and Identification & 01.00 \\
5. Botanical Exploration & 01.00 \\
6. Herbarium & 00.45 \\
7. Moss & 02.00 \\
8. Ferns & 01.30 \\
9. Gymnosperm & 02.00 \\
10. Angiosperm & 02.00 \\
11. Plant Utilization & 01.00 \\
12. Plant Propagation Techniques & 01.30 \\
\hline
\end{tabular}

Table 5. How Environmental Education in LIPI Botanic Gardens related to Sustainable Development

\begin{tabular}{|c|c|c|}
\hline SDGs & Explanation (ICSU \& ISSC, 2015) & $\begin{array}{l}\text { Practice in LIPI Botanic Gardens } \\
\text { (available topics in environmental education programs) }\end{array}$ \\
\hline Goal 6 & $\begin{array}{l}\text { Education and training increase skills and the } \\
\text { capacity to use natural resources more sustainably } \\
\text { and can promote hygiene. }\end{array}$ & $\begin{array}{c}\text { Plants for biofuel/biodiesel; Aromatic plants track; Medicinal Plants (introduction } \\
\text { and usage, tracking); Reduce, Reuse, Recycling Campaign; Urban Gardening and } \\
\text { Green Building; }\end{array}$ \\
\hline Goal 7 & $\begin{array}{c}\text { Educational programs can promote better energy } \\
\text { conservation and uptake of renewable energy } \\
\text { sources. }\end{array}$ & $\begin{array}{l}\text { Plants for biofuel/biodiesel; Aromatic plants track; Medicinal Plants (introduction } \\
\text { and usage); Reduce, Reuse, Recycling Campaign; Urban Gardening and Green } \\
\text { Building; }\end{array}$ \\
\hline Goal 11 & $\begin{array}{l}\text { Education can give people the skills to participate } \\
\text { in shaping and maintaining more sustainable cities, } \\
\text { and to achieve resilience in disaster situations. } \\
\text { Education can make a critical difference to }\end{array}$ & $\begin{array}{c}\text { Reduce, Reuse, Recycling Campaign \& workshop; "Save River Fest" to save water } \\
\text { and rivers; Gardening Day to encourage home gardening; Urban Gardening; Organic } \\
\text { Farming \& Organic Fertilizers. }\end{array}$ \\
\hline Goal 12 & $\begin{array}{l}\text { production patterns (e.g. with regard to the circular } \\
\text { economy) and to consumer understanding of more } \\
\text { sustainably produced goods and prevention of } \\
\text { waste. }\end{array}$ & $\begin{array}{l}\text { Reduce, Reuse, Recycling Campaign; Medicinal Plants; Natural Dye Coloring with } \\
\text { "membatik" activities; }\end{array}$ \\
\hline Goal 13 & $\begin{array}{l}\text { Education is key to mass understanding of the } \\
\text { impact of climate change and to adaptation and } \\
\text { mitigation, particularly at the local level. }\end{array}$ & $\begin{array}{l}\text { Save River Fest; Gardening Day; Free Seedling and Planting Day; Green Building; } \\
\text { Urban Gardening; Organic Farming \& Organic Fertilizers; Reduce, Reuse, Recycling } \\
\text { Campaign \& workshop. }\end{array}$ \\
\hline Goal 15 & $\begin{array}{l}\text { Education and training increase skills and capacity } \\
\text { to underpin sustainable livelihoods and to conserve } \\
\text { natural resources and biodiversity, particularly in } \\
\text { threatened environments. }\end{array}$ & $\begin{array}{l}\text { Gardening Day; Urban Gardening; Weekend Workshop for plant propagation; } \\
\text { Botanical Exploration; }\end{array}$ \\
\hline
\end{tabular}

\section{Discussion}

\section{Botanic Gardens as Historical Site}

All botanic gardens studied are not only historical remnants of physic gardens or an imperialistic past, especially KRB and KRC. At the early stage of their establishment, all gardens were based on taxonomic collections utilized by scientists or university for research and teaching. Despite a very limited budget for education, LIPI Botanic Gardens today not only still maintain their historical outstanding values but also develop more diverse practices in public engagement for environmental education especially for young people. This transformation is relevant to Sanders et al. (2018) that botanic gardens in modern era are much more people oriented, as they realized that people's perceptions of, and relationships with,

plants are crucial to not just visit numbers and financial support but also to the survival of biodiversity.

\section{Educational Tools and Materials}

All Gardens produce educational material to inform visitors. This material may be available on the website as itineraries, handouts or didactic activities, as also observed by Cerati (2018). The gardens also support students and teachers with a library and videos as a complement to educational visits, thus reinforcing didactics and the view that education in botanical gardens is an instrument of support to complement formal education. KRB, $\mathrm{KRC}$, and KREK optimizing their educational visits in a room or building such visitor education center, providing display and audio-visual materials.

The need of millennial visitors towards interactive activities were responded by the Gardens with development of new educational tools: 1) mobile application for self- 
guided tour built by KRB but includes tour in KRC, KRP and KREK; this mobile apps is downloadable from Play Store and free; namely "JAWARA" stands for Jelajah, Belajar, dan Wisata di Kebun Raya; 2) digital class on various topics using Edmodo social learning network (SLN); and 3) online games to introduce living plant collection in KRP, namely Kendil's Adventure (Table 3).

By using JAWARA, millennial visitors can experience more information about selected living collections, thematic parks, as well as heritage building/landmark, real time as long as their smartphones are connected to internet. This mobile apps sounds effective for millennial visitors in outdoor education, since Schneider (2016) stated that millennial generation is super-connected, which means they have access to the web at home, at work, and on mobile devices. To support internet connection for visitors, KRB in collaboration with a private company provide free public wifi in 27 points throughout the Garden.

Millennial students prefer hands-on learning rather than lectured materials (Beard et al, 2007). With their interest in and adeptness to information technology, increased integration of technology into outdoor environmental education in botanic gardens is essential. LIPI Botanic Gardens combine the needs with developing hands-on materials in hard copies for either group or individual project under various themes.

\section{Educational Activities}

Educational activities in all BGs studied are directed especially to students, an important part of the total number of visitors. As regards GSPC Target 14, educational visits are held in all Gardens and usually explore living collections. Visits to living collection is indeed favorable to interaction of society with the garden (Cerati, 2018).

Outreach program is rarely carried out in LIPI Botanic Gardens except KRC. KRC has practiced outreach program actively through collaboration with nearby schools in making and monitoring school gardens, and still on going until present. KRC also developed web-based courses using social learning network (SLN) in Edmodo website, underlined 12 subjects, equipped with video and e-book (Table 4).

In the last three years, KRB is improving its events with face-to-face workshops (weekend workshops) under different topics web-based courses, and student group projects with role playing (for example: treasure hunt games). We also observed that KRB is the most active botanic gardens in holding community events, at least 5 times in a year since 2016. This face-to-face learning activity is also get high attention from public and visitors, make this method is very potential to embrace young people for their awareness towards plant diversity, its proneness to extinction, and the importance of plant conservation. Beard et al. (2007) mentioned that web-based courses, web supported face-to-face courses, group projects with role playing, are to name some of teaching strategies for millennial students. As millennial generation has passionate in raising community as extracted from Howe and Strauss ideas by Simões \& Gouveia (2008), it would be more benefit for botanic gardens host- ing more community events to expand their educational target for millennial visitors.

\section{Implementing Education for Sustainable Development in Practice}

Education, training and learning tools and techniques in botanic gardens need to be properly recognized in addressing environmental and plant conservation issues to millennial visitors. These tools and techniques have to be relevant also with SDGs. According to ICSU ISSC (2015), education is relevant to all SDGs but especially SDGs $1,2,3,5,8,12,13$, and 16. But in terms of addressing plant conservation and environmental mindset awareness, education in botanic gardens are directly relevant to SDGs $6,7,11,12,13,15$ as we summarized in Table 5. As we observed, LIPI Botanic Gardens' educational and training topics are given in different ways: hands-on, talk show, workshop, video/tutorials, or digital class in social learning network tools (SLN).

The only LIPI Botanic Gardens using SLN was KRC in the period of research. KRC used Edmodo as online learning environment is to broadening the coverage of education in interactive way where the student is assisted by teachers or educators to acquire particular knowledge or skill that cannot be acquired without assistance at that point in time. Through Edmodo, the learners can choose and work with materials shared in line with their preferences and goals at any time and from any places without necessarily visit the Garden.

\section{Reflections for Botanic Gardens Management}

Botanic gardens is intimate space where nature and culture meet. Botanic gardens are also resources for environmental education in its broadest sense, as various elements of knowledge can be integrated within an excursion or field trip. Thus, their education programs and activities must inevitably be concise, message-obtainable, interactive and up to date. All LIPI Botanic Gardens have to improve and regularly update their official website because website is a kind of business card of an organization, where people can look through what is inside. They have to make their website more interactive with ease-tofind information about certain topics and learning.

All the major international strategies for biodiversity conservation and sustainable living (CBD, Agenda 21, SDGs, GSPC), have emphasized the importance of environmental education in the struggle to halt biodiversity loss; and botanic gardens have an important role to play in implementing these strategies. Related to educate millennial visitors, some future challenges in a changing world are arising:

1. evaluating the influence of botanic gardens toward millennial visitors,

2. promoting scientific-environmental literacy,

3. integrating education more into sustainable development and current environmental issues,

4. collaborating with communities,

5. developing citizen science program, and

6. allocating more budget for education programs. 


\section{Acknowledgment}

Authors thank Sholehuddin (Cibodas Botanic Gardens), Renata Lusilaora Siringoringo and Gde Wawan (Bali Botanic Gardens), Titut Yulistiani (Purwodadi Botanic Gardens) for their assistance in providing data and information.

\section{References}

Beard DF, Schweiger D, Surendran K. 2007. Bridging the Academic / Industrial Chasm for the Millennial Generation. Information Systems Education Journal 5 (33). Retrieved from http://isedj.org/5/33/.

Bennett BC. 2014. Learning in Paradise: the Role of Botanic Gardens in University Education. In C. L. Quave (ed.). Innovative Strategies for Teaching in the Plant Sciences. doi: 10.1007/978-14939-0422-8 13. New York: Springer Science + Business Media.

Botanic Gardens Conservation International. 1994. Environmental Education in Botanic Gardens: Guidelines for Developing Individual Strategies. Richmond, UK: Botanic Gardens Conservation International.

Botanic Gardens Conservation International. 2012. Communities in Nature: Growing the Social Role of Botanic Gardens. Retrieved from http://www.bgci.org/education.

Cerati TM. 2018. Education and training in Brazilian botanical gardens: are we achieving GSPC targets? Rodriguésia 69(4): 1603-1612.

Chang Li-Shin, Bisgrove RJ, Ming-Yi Liao. 2008. Improving Educational Functions in Botanic Gardens by Employing Landscape Narratives. Landscape and Urban Planning 86(3): 233-247, https://doi.org/10.1016/j.landurbplan.2008.03.003.

Convention on Biological Diversity. 2001. Global Strategy for Plant Conservation: 2011-2020. Richmond, UK: Botanic Gardens Conservation International.

ICSU, ISSC. 2015. Review of Targets for the Sustainable Development Goals: The Science Perspective. Paris: International Council for Science (ICSU)
Leicht A, Heiss H, Byun WJ. (eds). 2018. Issues and Trends in Education for Sustainable Development. Paris: The United Nations Educational, Scientific and Cultural Organization, UNESCO Publishing

Pemerintah Republik Indonesia. 2011. Peraturan Presiden No. 93 tahun 2011 tentang Kebun Raya. Jakarta: Sekretariat Negara.

Purnomo DW, Magandhi M, Kuswantoro F, Risna RA, Witono JR. 2015. Developing Plant Collections on the Regional Botanic Gardens in Framework of Plant Conservation Strategy in Indonesia. Buletin Kebun Raya 18(2): 111-124.

Rivkin MS. 2000. Outdoor Experiences for Young Children. ERIC Digest (ED448013 2000-12-00. Retrieved from http://www.eric.ed.gov.

Sanders DL, Ryken AE, Stewart K. 2018. Navigating Nature, Culture and Education in Contemporary Botanic Gardens. Environmental Education Research 24(8): 1077-1084. doi: 10.1080/13504622.2018.1477122.

Scheiner CD. 2016. The Hidden Value of Millennial Visitors to Cultural Organizations. Retrieved from https://www.colleendilen.com/2016/02/03.

Sharrock S. 2011. GSPC Global Strategy for Plant Conservation: A Guide to the GSPC, All the Targets, Objectives, and Facts. Richmond, UK: Botanic Gardens Conservation International.

Simões L., e Gouveia L. 2008. Targeting the Millennial Generation. III Jornadas de Publicidade e Comunicação. A Publicidade para o consumidor do Séc. XXI. UFP. Porto. 10 de Abril.

Waylen K. 200). Botanic Gardens: Using Biodiversity to Improve $\mathrm{Hu}$ man Well-Being. Richmond, UK: Botanic Gardens Conservation International.

Williams SJ, Jones GPG, Gibbons JM, Clubbe C. 2015. Botanic Gardens Can Positively Influence Visitors' Environmental Attitudes. Biodiversity Conservation 24:1609-1620. doi: 10.1007/s10531-015-0879-7.

Wyse-Jackson P, Sutherland LA. 2000. International Agenda for Botanic Gardens in Conservation. Richmond, UK: Botanic Gardens Conservation International. 